\title{
Course experiences, satisfaction and career intent of final year pre-registration Australian pharmacy students
}

\author{
Grace SHEN, Romano FOIS, Lisa NISSEN, Bandana SAINI.
} Received (first version): 18-Nov-2013 Accepted: 27-May-2014

\begin{abstract}
${ }^{*}$
Background: In Australia, the profession of pharmacy has undergone many changes to adapt to the needs of the community. In recent years, concerns have been raised with evidence emerging of workforce saturation in traditional pharmacy practice sectors. It is not known how current final year pharmacy students' perceive the different pharmacy career paths in this changing environment. Hence investigating students' current experiences with their pharmacy course, interaction with the profession and developing an understanding of their career intentions would be an important step, as these students would make up a large proportion of future pharmacy workforce Objective:. The objective of this study was thus to investigate final year students' career perspectives and the reasons for choosing pharmacy, satisfaction with this choice of pharmacy as a tertiary course and a possible future career, factors affecting satisfaction and intention of future career paths.

Methods: A quantitative cross sectional survey of final year students from 3 Australian universities followed by a qualitative semi-structured interview of a convenience sample of final year students from the University of Sydney.

Results: 'Interest in health and medicine' was the most important reason for choosing pharmacy $(n=238)$. The majority of students were 'somewhat satisfied' with the choice of pharmacy (35.7\%) as a course and possible future career. Positive associations were found between satisfaction and reasons for joining pharmacy such as 'felt pharmacy is a good profession' $(p=0.003)$ while negative associations included 'joined pharmacy as a gateway to medicine or dentistry' $(p=0.001)$. Quantitate and qualitative results showed the most frequent perception of community pharmacy was 'changing' while hospital and pharmaceutical industry was described as 'competitive' and 'research' respectively. The highest career intention was community followed by hospital pharmacy. Conclusion: Complex factors including university experiences are involved in shaping students' satisfaction and perception of career. This may relate to challenges in the community pharmacy sector, job opportunities in hospital and limited understanding of the pharmaceutical industry. The results offer insight for the profession in terms of entry into various roles and also to pharmacy educators for their roles in shaping curricula and
\end{abstract}

\footnotetext{
"Grace SHEN. BPharm(Hons). Faculty of Pharmacy, University of Sydney. Sydney, NSW (Australia) Romano FOIS. BPharm, PhD, MPS. Faculty of Pharmacy, University of Sydney. Sydney, NSW (Australia). romano.fois@sydney.edu.au Lisa NISSEN. BPharm, PhD. School of Clinical Sciences Medical Radiation Sciences | Paramedic Science | Pharmacy | Podiatry Queensland University of Technology. Brisbane, QLD (Australia). I.nissen@qut.edu.au Bandana SAINI. BPharm, MPharm, MBA, PhD, Grad Cert Ed Studies (Higher Edu). Faculty of Pharmacy, University of Sydney. Sydney, NSW (Australia).

bandana.saini@sydney.edu.au
}

placement experiences that attract future graduates to defined career pathways in pharmacy.

Keywords: Students, Pharmacy; Career Choice; Personal Satisfaction; Pharmacists; Pharmaceutical Services; Australia

\section{INTRODUCTION}

Changes in health care systems, health care workforce supply issues, ageing populations, emerging chronic diseases and changing consumer expectations have re-engineered pharmacy practice in many developed nations across the globe. Over the last two decades, pharmacy has transitioned from a focus on dispensing and supplying of medications to the provision of a range of health services spanning prevention to palliation, to address patients' needs and expectations. ${ }^{1,2}$

In Australia, the pharmacy profession has undergone many practice paradigm shifts aligned with changes in other developed countries. ${ }^{3}$ The pharmacy practice environment is unique in Australia, given the subsidised access to medications that Australians enjoy under the Pharmaceutical Benefits Scheme (PBS) and the practice incentive payments and practice research activities funded through the 5-yearly Community Pharmacy Agreements with the Commonwealth Government. $^{3}$ These agreements negotiate dispensing fees, remuneration for a limited range of services, such as Home Medicines Review, and the allowed 'mark-up' for medications listed on the PBS. ${ }^{3}$ [Note: Mark up refers to the set price mark up on top of the wholesale price that Australian pharmacists are allowed to charge, which is intended to cover storage and handling costs]. ${ }^{3}$ However, recently the pharmacy profession in Australia has experienced tumultuous times due to environmental catalysts such as reduced margins on wholesale prices, generic pricing changes and patent expiry for many blockbuster therapies, requirements of wholesale price disclosure to patients, the increasing competition of discount pharmacies and the de-scheduling of several products from 'pharmacy only' medicines to allowed sales in supermarkets. ${ }^{4}$ The effect of these environmental pressures is evident in data released from the Australia Bureau of Statistics (ABS) which indicates a decline in community pharmacy sales turnover. ${ }^{5}$ Further, a recent report highlights that many pharmacies have gone into bankruptcy in 2011-12. ${ }^{6}$ Downstream effects of these economic crises are likely to have implications on the 
'demand' for employable pharmacists. Moreover, the growing pool of registered pharmacists has been the object of much media coverage in the pharmacy profession with an apparent oversupply of pharmacists being attributed to an increasing production of pharmacy graduates. ${ }^{7}$

Currently, there are 19 universities in Australia offering a pharmacy degree, with a forecast of 1780 students expected to graduate in $2014 .^{7,8}$ This is certainly an increase compared to a decade ago, and may have eventuated through a shortage of pharmacy workforce (registered pharmacists) reported in 1999, whereupon the Australian Government had supported more funded seats in Universities for the study of pharmacy. The recent environmental pressures and the simultaneous increase in pharmacy schools and graduates has received the attention of professional pharmacy bodies including the Pharmacy Guild of Australia (which represents pharmacy owners), describing this phenomenon as "unsustainable" and of "significant concern". In particular, this increase has serious implications for students to secure an intern position and future employment in their professional career. ${ }^{8,10,11}$ Combined, these factors affect real or perceived job security, with current pharmacy students embracing a future of uncertain employment prospects, and some pharmacists choosing to leave the profession. ${ }^{12-14}$ It is therefore timely to investigate students' current perspective of pharmacy career options to develop a better understanding of students' career intentions and future workforce distribution and retention.

The scant literature in this area suggests that career perceptions are not 'static', but rather many factors influence how pharmacy students think about pharmacy as a career option. It appears that factors which motivate people to choose pharmacy, satisfaction with the course and socio-ethnic background all enact a role in shaping career related perceptions. ${ }^{15-29}$ Many extant career choice/career development theories do not explain these findings well, perhaps as they do not take into account contemporary health care contexts or the social milieu of students. ${ }^{30,31}$ Bronfenbrenner's socio-ecological model offers a framework that allows for the complexity of career development to be emphasized and has four interconnected components; often referred to as the "processperson context-time model" (PPCT). ${ }^{32,33}$ A study of Australian nursing students' career perceptions showed that this theory has utility in defining career related research in the health care professions in Australia. ${ }^{31}$ The first component is the process of career development, which involves the dynamic relationship between the "individual and the context". ${ }^{32}$ The second component is the person (i.e., the student) who bears their own biological, cognitive, emotional, and behavioural characteristics. $^{32}$ The third component comprises the context where the human development occurs. ${ }^{32}$ It is seen as a set of nested systems-the microsystem, the mesosystem, the exosystem, and the macrosystem (Figure 1). ${ }^{32}$ The last component is time which reflects the chronosystem that moderates change across the life course. ${ }^{32}$ Figure 1 depicts the subjective application of the Bronfenbrenner's socio-ecological model to the current Australian pharmacy students' career perspective. This provides a framework for exploring constructs that shape career intent, satisfaction with career choice, and perspectives about different career pathways. This framework serves as a working hypothesis for the study; specifically that individual factors affect choice of pharmacy as a course and the process of career choices is shaped by the education process i.e. placement experience and satisfaction with course.

To the authors' knowledge there are no current data on final year Australian pharmacy students' perception of different career pathways in their professional outlook as pharmacists. Thus the aim of the research was to explore career related perspectives of pharmacy students using a socioecological theoretical framework with several objectives. These included investigating final year pharmacy students':

1. Reasons for choosing pharmacy as a course of study at University

2. Satisfaction with the choice to study pharmacy and factors affecting satisfaction

\section{Intention of pursuing specific career pathways}

\section{Perceptions of different career pathways}

In the context of the Bronfenbrenner's model these variables are collectively referred to as career perspectives.

\section{METHODS}

Given that there is limited ground work in this area, a sequential mixed methods approach was undertaken to strengthen the research. It was thought that the quantitative and qualitative streams would generate complementary data.

The protocol for the research study was approved by the University of Sydney Human Research Ethics Committee (HREC) and was divided in 2 parts:

\section{Part 1. Quantitative: (survey)}

\section{Survey instrument development}

A pre-coded survey instrument separated into 6 sections (30 questions) was developed by an exploration of the international literature regarding students' reasons for choosing pharmacy as a career, factors influencing their career intention and was reviewed by the researchers independently to provide reliability. ${ }^{15-29}$ The sections and the core variables in the survey are described in Table 1.

\section{Recruitment of participants}

Final year pharmacy student cohorts from 3 Australian universities were invited to participate in part 1. The participant recruitment process is outlined in Figure 2. Participation was voluntary and completion of questionnaire was taken as sign of consent. Anonymity was ensured. Measures were taken to ensure participants only filled the survey 


\section{Chronosystem- time related effects on career development}

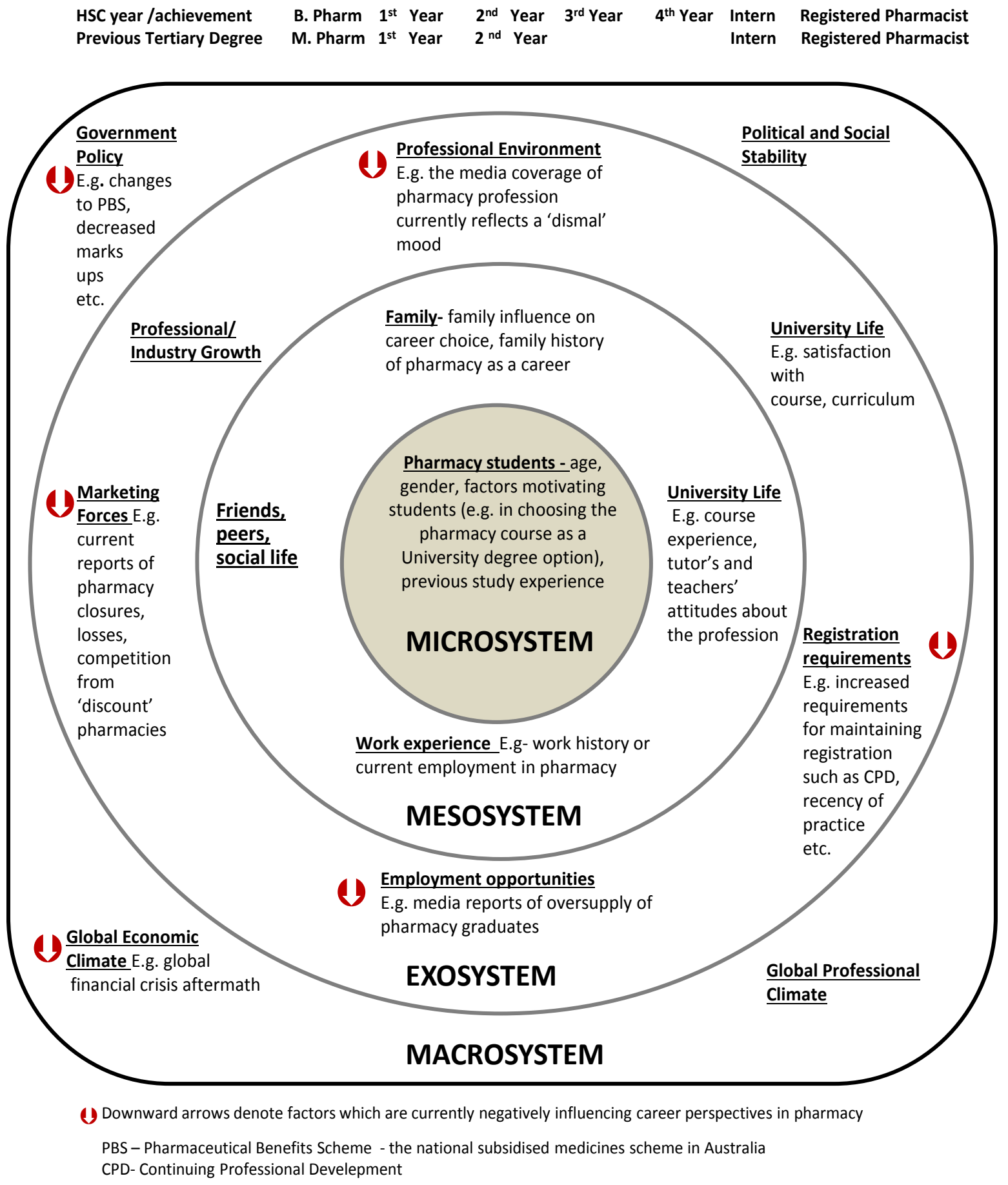

Figure 1. A framework explaining socio-ecological factors affecting career development perspectives for pharmacy students (Adapted from Bronfenbrenner, 1992).

once by using questionnaire coding based on unique identifiers anonymously created for each participating student, these identifiers were derived from their Student Identification number and date of birth permutations. A single reminder email message was sent to all enrolled students eligible for participation at all three Universities. The final year cohort was eligible from both the Bachelors and Masters courses which lead to registration. [The two courses are similar with respect to pharmacy and professional content. The graduate entry level of the Masters course allows streamlining for a shorter duration (2 versus 4 years) based on set pre- basic science prerequisites that graduates would have completed earlier]. The different approaches for recruitment were dictated by the methods the Universities were willing to allow for researchers to approach and recruit students. 


\begin{tabular}{|c|c|c|}
\hline Sections & Key variables & $\begin{array}{l}\text { Relation to Bronfenbrenner's socio- } \\
\text { ecological framework }\end{array}$ \\
\hline 1 & $\begin{array}{l}\text { Demographic data such as age, gender, ancestry, family connection to } \\
\text { pharmacy, previous tertiary degree and placement experience. }\end{array}$ & $\begin{array}{l}\text { Related to the 'person' and 'context' factors } \\
\text { in the framework. }\end{array}$ \\
\hline 2 & $\begin{array}{l}\text { This section explored factors influencing career perspectives at the } \\
\text { start of the course and satisfaction with choice after course experience. } \\
\text { Factors motivating students to have selected pharmacy as a course: } \\
\text { (17 reasons identified from literature review and respondents asked to } \\
\text { rate on a 5-point Likert scale, where } 1=\text { not important to } 5=\text { very } \\
\text { important). } \\
\text { Satisfaction with the course: } \\
\text { (5-point Likert scale ranking for a statement about satisfaction with the } \\
\text { course, ranging from } 1=\text { not at all satisfied to } 5=\text { extremely satisfied). }\end{array}$ & $\begin{array}{l}\text { Although the research was intended to focus } \\
\text { on one time point (students about to enter } \\
\text { the profession), we deemed that asking } \\
\text { about satisfaction with course studied over } 4 \\
\text { years would be a measure of 'process' with } \\
\text { respect to the framework. }\end{array}$ \\
\hline 3 & $\begin{array}{l}\text { Career intention: } \\
\text { Asking respondents which career path they intended to purse (e.g. } \\
\text { community pharmacy, hospital pharmacy, industry etc). }\end{array}$ & Relates to the 'process' in the framework \\
\hline 4 & $\begin{array}{l}\text { Perception of different career pathways by using a common marketing } \\
\text { technique, Top Of Mind Awareness (TOMA): } \\
\text { Asking respondents to list three important descriptors when thinking } \\
\text { about a career in ....... (community, hospital pharmacy etc). }\end{array}$ & Relates to the 'process' in the framework \\
\hline 5 & Additional comments - free text & NA \\
\hline 6 & Invitation in part 2 of the research (i.e. the semi-structured interview) & NA \\
\hline \multicolumn{3}{|c|}{$\begin{array}{l}\text { a. Top of mind awareness measures the specific perception coming first in students' mind when thinking of particular career } \\
\text { pathways. }\end{array}$} \\
\hline
\end{tabular}

Part 2. Qualitative: (semi structured interviews)

Recruitment of participants

Invitations to the interview were included for students from the University of Sydney on the last page of the survey and volunteers were asked to contact the chief investigator (BS) by email. The date, time and location of each interview were arranged between the primary investigator (GS) and the volunteer participants from the University of Sydney. Consent forms were signed by the participants prior to the interview, which was audio recorded and transcribed. The interview was separated into 6 aspects as described in Table 2 and the primary focus of the interview was to explore students' career perceptions of community, hospital and industrial pharmacy.

\section{Statistical analysis}

Survey data

Statistical analyses of survey data were conducted using SPSS (Version 20, Armonk, NY) with significance set at a p-value 0.05 or lower. The Kolmogorov-Smirnov test was used to determine the distribution of the Likert-scale data. Demographic information was described using frequency analyses. The interpolated median was calculated for Likert-scale data for students' reasons for choosing to study pharmacy. Non-parametric tests were used when comparing responses to satisfaction with choosing to study pharmacy across categorical groups (Mann-Whitney $U$ test for 2 groups and Kruskal-Wallis for $>2$ groups). Correlations between importance of reasons for choosing to study pharmacy and degree of satisfaction with this choice were investigated by calculating Spearman's rho and its significance for each reason.

Interview data

The interviews were transcribed verbatim and entered into NVivo (Version 9, QSR International Pty Ltd) for analyses. Key themes around career perceptions emanating from interviews were identified and coded by the primary investigator. The transcripts and coding scheme were independently reviewed by a second and experienced investigator (BS) for reliability. A word frequency query was also conducted to find the most common theme for perception of different career pathways post-graduation. The data collected from Section 4 of the survey was also thematically analysed.

\section{RESULTS}

\subsection{Demographics}

A total of 261 questionnaires were collected and 238 were included in the final data analysis based

\begin{tabular}{|c|l|}
\hline \multicolumn{2}{|c|}{ Table 2. Key variables of the interview instrument } \\
\hline Sections & \multicolumn{1}{c|}{ Key variables } \\
\hline 1 & Demographic information such as age and gender \\
\hline 2 & $\begin{array}{l}\text { Motivation and satisfaction to study pharmacy } \\
\text { Key question: May I please ask you to describe in depth all the reasons that motivated you to choose } \\
\text { pharmacy? }\end{array}$ \\
\hline 3 & $\begin{array}{l}\text { Perception of community, hospital and industry pharmacy } \\
\text { Key questions: Would you tell us your thoughts about community, hospital and pharmaceutical industry? }\end{array}$ \\
\hline 4 & Internship and future career \\
\hline 5 & $\begin{array}{l}\text { Focus on pharmaceutical industry } \\
\text { Key question: What are your opinions about a career in pharmaceutical industry? }\end{array}$ \\
\hline 6 & Support provided by the faculty and general comments \\
\hline
\end{tabular}




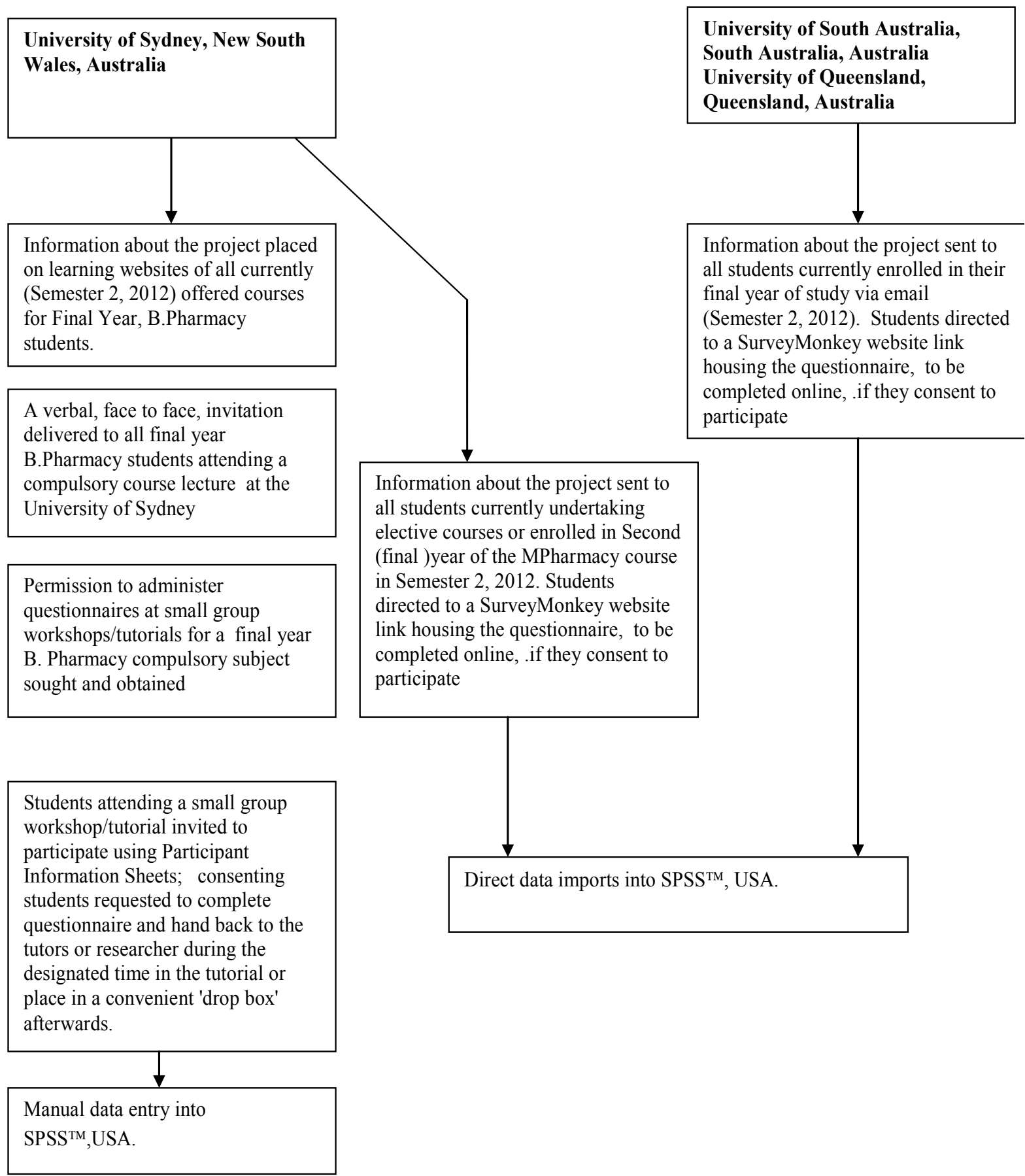

Figure 2. Flow diagram of survey distribution

on minimum completion threshold. The threshold was set at completion of question relating to satisfaction. Of the 238 responses, $82.4 \%(n=196)$ of the participants were final year bachelor and master of pharmacy students from the University of Sydney, $13.9 \% \quad(n=33)$ and $3.8 \% \quad(n=9)$ from University of Queensland and South Australia respectively (bachelor degree only). The University of Sydney response rate was 50\% (196/392). Information on the number of enrolled students was not available for the other Universities. Participants' age ranged from 19 to 55 , with a mean of 22 years. Table 3 presents demographic data of final year pharmacy students participated in the survey.

\subsection{Placement experience}

The 3 most common placement experiences were community $(100.0 \%, n=238)$ and hospital $(66.0 \%$, $\mathrm{n}=157$ ) pharmacy, followed by pharmaceutical industry $(22.7 \%, \quad n=54)$ [Note: students were allowed to choose more than one option]. Other placement experiences included were research settings such as university summer projects $(19.3 \%$, $\mathrm{n}=46$ ) and not for profit organisations including the Pharmaceutical Society of Australia $(15.1 \%, n=36)$. Figure 3 presents the percentage of respondents who had placement experience at the 3 most common settings and also the percentage of which these respondents ranked the experience as either good or very good. There were no significant 


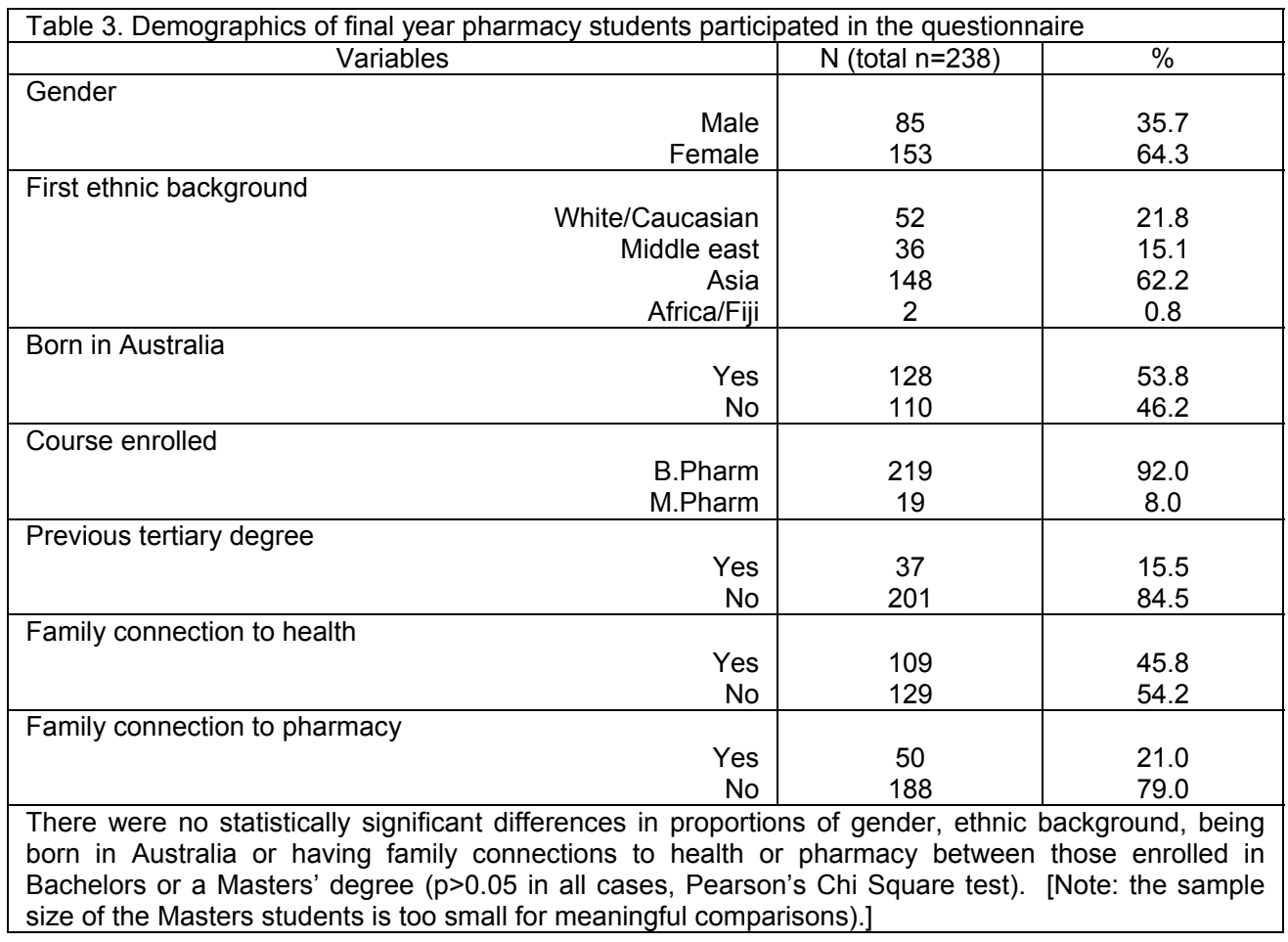

differences in satisfaction ratings between Bachelors or Masters students for any of the placements $(p>0.05$, Mann Whitney U Test).

\subsection{Importance of reasons to study pharmacy}

The ranked importance of the 17 reasons to study pharmacy is listed in Table 4 by compiling data from Likert scale questions. Of the 238 respondents, $92.4 \%(n=220)$ ranked 'interested in health and medicine' as important/very important reason to study pharmacy followed by 'felt that health related disciplines are good professions' $(87.8 \%, n=209)$ and 'felt that pharmacy is a good profession' $(76.1 \%, n=181)$. The reason 'joined pharmacy because my friends were doing it' and 'family members own a pharmacy' were the least important reasons for respondents.
2.1 Satisfaction with the decision to study pharmacy and associated factors

When respondents were asked to rank satisfaction with their decision to study pharmacy, $5.0 \% \quad(n=12)$ were extremely satisfied, $20.2 \% \quad(n=48)$ were very satisfied, $35.7 \% \quad(n=85)$ were somewhat satisfied, $26.1 \% \quad(n=62)$ were slightly satisfied and $13 \%$ $(\mathrm{n}=31)$ were not at all satisfied.

The distributions of satisfaction across different demographic categorical variables were compared using non-parametric tests. These revealed the distribution of satisfaction was significantly different among groups of different ethnicity $(p=0.029)$ or in the case of students with versus without a previous tertiary degree $(p=0.044)$. Students who reported their main ancestry as Caucasian had higher

\section{Placement experience}

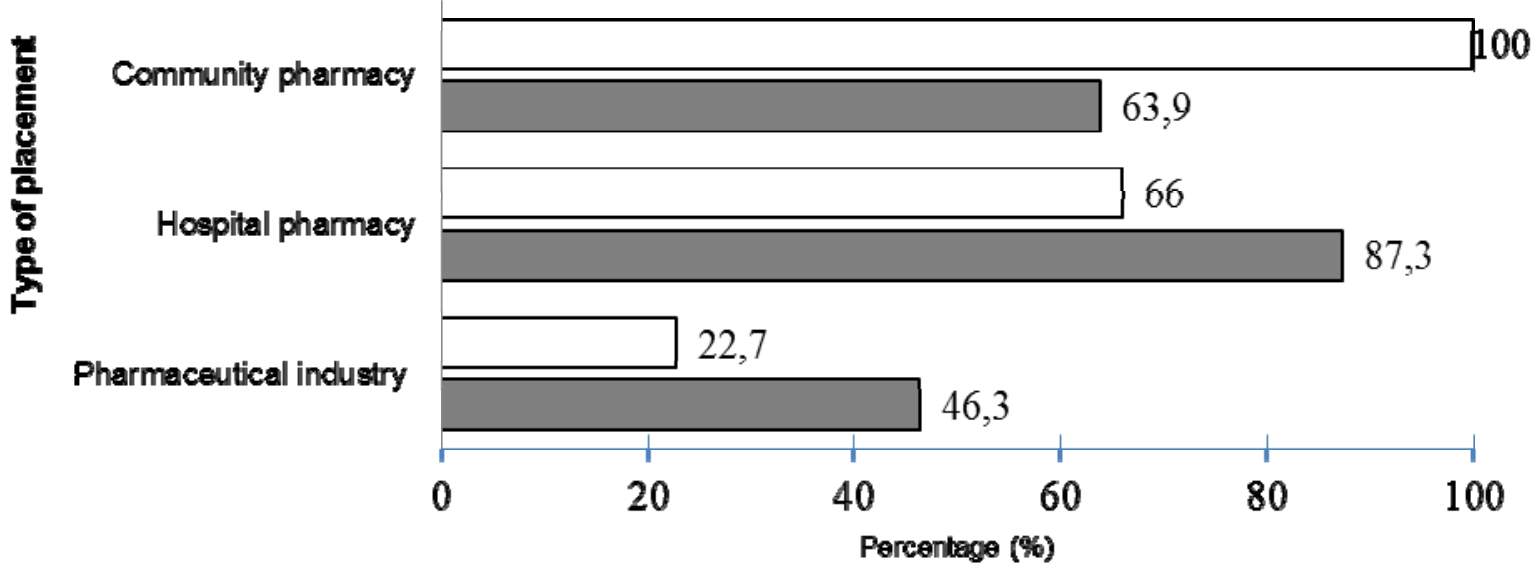

口\% of students who hed placement et the site $\quad$ Q\% of goodvery good plecement experience at the site

Figure 3. Percentage of respondents who had placement at community, hospital and industry pharmacy and percentage of those who had good/very good experience at the sites. 
Table 4. Ranking of the importance of the reasons/motivation to study pharmacy (ranked on 5 Likert scale ranging from 1 =not important to 5 =very important)

\begin{tabular}{|c|c|c|c|c|c|c|}
\hline \multirow[t]{2}{*}{ Reasons } & \multicolumn{5}{|c|}{$\begin{array}{c}\text { Number of students choosing the importance } \\
\text { of each reasons }\end{array}$} & \multirow{2}{*}{$\begin{array}{l}\text { Interpolated } \\
\text { median }\end{array}$} \\
\hline & 1 & 2 & 3 & 4 & 5 & \\
\hline Interested in health and medicine & 1 & 12 & 5 & 97 & 123 & 4.5 \\
\hline Felt that health related disciplines are good professions & 3 & 11 & 15 & 135 & 74 & 4.2 \\
\hline Felt that pharmacy is a good profession & 7 & 23 & 27 & 133 & 48 & 4.0 \\
\hline Felt that pharmacy has a good job prospect & 14 & 19 & 40 & 111 & 54 & 3.9 \\
\hline Did well at chemistry/biology in higher school certificate & 30 & 28 & 32 & 95 & 53 & 3.8 \\
\hline $\begin{array}{l}\text { Am a people person and wanted a career with high levels of } \\
\text { patient contact }\end{array}$ & 17 & 26 & 46 & 96 & 53 & 3.8 \\
\hline Felt that pharmacy would have a high income & 26 & 35 & 49 & 86 & 42 & 3.6 \\
\hline $\begin{array}{l}\text { Had family members who encouraged a health related field of } \\
\text { study }\end{array}$ & 51 & 26 & 41 & 85 & 35 & 3.5 \\
\hline Felt that pharmacy provides a diversity of options & 27 & 35 & 77 & 65 & 34 & 3.2 \\
\hline Wanted to own a pharmacy & 62 & 34 & 60 & 53 & 29 & 2.9 \\
\hline Had family members who encouraged pharmacy training & 80 & 23 & 48 & 56 & 31 & 2.8 \\
\hline Joined pharmacy as a gateway to dentistry/medicine & 102 & 27 & 52 & 35 & 22 & 2.1 \\
\hline $\begin{array}{l}\text { Joined pharmacy because I want to work for a pharmaceutical } \\
\text { company }\end{array}$ & 111 & 21 & 42 & 50 & 14 & 1.9 \\
\hline Joined pharmacy as I wanted to undertake research in medicine & 112 & 26 & 49 & 37 & 14 & 1.8 \\
\hline Joined pharmacy because I want to join the government sector & 112 & 27 & 57 & 34 & 8 & 1.8 \\
\hline Family members own a pharmacy & 158 & 13 & 48 & 9 & 10 & 1.3 \\
\hline Joined pharmacy as my school friends were doing it & 173 & 15 & 42 & 6 & 2 & 1.2 \\
\hline
\end{tabular}

Note: There were no statistically significant differences in the median importance for any of the reasons for choosing pharmacy as a course at University between Bachelors or Masters students ( $p>0.05$, Wilcoxon Signed Rank Test). Of course the numbers of Masters students are too small to draw meaningful group comparison.

proportions expressing satisfaction as compared to those reporting an Asian or middle eastern background. This was the same case for those with previous tertiary degrees.

When the ratings of satisfaction levels were correlated with ratings for different reasons for choosing to study pharmacy, positive (albeit weak) associations were revealed for 'interested in health and medicine'(Spearman's rho $=0.176, p=0.007$ ), 'felt that pharmacy is a good profession' (Spearman's rho $=0.129, \quad p=0.047$ ), 'felt that pharmacy provides a good diversity of options' (Spearman's rho $=0.191 \mathrm{p}=0.003$ ) while negative associations were revealed for 'felt that pharmacy would have a good income' (Spearman's rho=$0.151, p=0.020$ ), 'had family members who encouraged a health-related field of study' (Spearman's rho $=-0.153, \quad p=0.018$ ), 'family members own a pharmacy' (Spearman's rho=-
0.135, $p=0.037$ ), 'joined as a gateway to medicine/dentistry' (Spearman's rho $=-0.223$, $\mathrm{p}<0.001$ ) and 'joined pharmacy because I want to join the government sector in health/pharmaceutical policy' (Spearman's rho $=-0.142, \quad p=0.029$ ). A positive association was also observed between ratings of satisfaction in studying pharmacy and the rating of the community-pharmacy placement experience (Spearman's rho $=0.401, p<0.001$ ). These findings are described in Table 5. We further segregated the Bachelors students in the data set and repeated the satisfaction- reason for joining pharmacy associations. The results were the same as for the mixed sample- except for two instances. One, a significant association between satisfaction and joining pharmacy because of affinity for high people contact careers $(n=224$, spearman's rho=0.132, $p=0.04$ ) was found, unlike in the combined sample. Secondly, the association between satisfaction and joining pharmacy because

\begin{tabular}{|c|c|c|}
\hline Total $n=238$ & Satisfaction with & of pharmacy \\
\hline Reasons for choosing pharmacy & Spearman's rho & $\mathrm{P}$ value ${ }^{\mathrm{a}}$ \\
\hline 1. Interested in health and medicine & 0.176 & $0.007^{\wedge}$ \\
\hline 2. Did well at chemistry/biology in Higher school certificate & 0.106 & 0.104 \\
\hline 3. Am a people person and wanted a career with high levels of patient contact & 0.079 & 0.226 \\
\hline 4. Felt that pharmacy is a good profession & 0.129 & 0.047 \\
\hline 5. Felt that health related disciplines are good professions & 0.014 & 0.829 \\
\hline 6. Felt that pharmacy has a good job prospect & -0.014 & 0.825 \\
\hline 7. Felt that pharmacy provides a diversity of options & 0.191 & $0.003^{\wedge}$ \\
\hline 8. Felt that pharmacy would have a high income & -0.151 & $0.020^{\wedge}$ \\
\hline 9. Wanted to own a pharmacy & -0.061 & 0.346 \\
\hline 10. Had family members who encouraged pharmacy training & -0.063 & 0.330 \\
\hline 11. Had family members who encouraged a health related field of study & -0.153 & $0.018^{\wedge}$ \\
\hline 12. Joined pharmacy as my school friends were doing it & -0.093 & 0.154 \\
\hline 13. Family members own a pharmacy & -0.135 & $0.037^{\wedge}$ \\
\hline 14. Joined pharmacy as a gateway to dentistry or medicine & -0.223 & $0.001^{\wedge}$ \\
\hline 15. Joined pharmacy as I wanted to undertake research in medicine & -0.065 & 0.318 \\
\hline 16. Joined pharmacy because I want to work for a pharmaceutical company & -0.109 & 0.092 \\
\hline $\begin{array}{l}\text { 17. Joined pharmacy because I want to join the government sector in } \\
\text { health/pharmaceutical policy }\end{array}$ & -0.142 & $0.029^{\wedge}$ \\
\hline
\end{tabular}


Table 6. Final year pharmacy students' career intention in the next 5 years.

\begin{tabular}{|l|c|}
\hline \multicolumn{1}{|c|}{ Career intentions } & $\mathrm{N}$ \\
\hline Community & 120 \\
\hline Hospital & 80 \\
\hline Ownership & 37 \\
\hline Industry & 25 \\
\hline Overseas & 14 \\
\hline No intention to pursue pharmacy & 13 \\
\hline Research & 11 \\
\hline Public health & 7 \\
\hline Government department & 3 \\
\hline Government regulatory bodies & 2 \\
\hline Academia & 2 \\
\hline
\end{tabular}

Total number exceeds total number of students as the questionnaire allowed up to 2 intentions (number of respondents $=220$; total $n=238$ )

of higher income expectations was not significant for the undergraduate sample $(n=224$, Spearman's rho $=-0.072, p=0.271$ ).

\subsection{Intention of career pathway}

Students were given up to 2 choices for intended career pathway in the next 5 years following registration. Out of 238 respondents, $220(92.4 \%)$ indicated intended career with community pharmacy as the highest career intention followed by hospital pharmacy and a small proportion of students also indicated ownership. Of concern is the total proportion of students that were 'not sure', have 'no intention to pursue pharmacy' and indicated 'others'. This possibly indicates interest in pursuing alternative career pathways such as medicine or dentistry as depicted in Table 6.
4.1 Common themes on perceptions about different career pathways post-graduation

Using the TOMA (Top of Mind Analysis) technique (Section 4 of questionnaire), students were asked to provide descriptors for key career paths in pharmacy. A total of 623 descriptive words were collected for community pharmacy followed by 577 and 492 descriptive words for hospital and industry pharmacy respectively. The most frequent theme of community pharmacy was "changing", "business" and "patient contact" while hospital pharmacy was described as "clinical/knowledge", "competitive" and "education/learning". The pharmaceutical industry was most commonly described as "business/cooperation", "research", "experience" and "money".

Interview

A total of 25 students from the University of Sydney participated in part 2 (interview) of the research. Ten students were male and 15 were female. Twelve of the students were enrolled in the honours curriculum, 12 were in the standard stream while 1 was from the Master degree. For these 3 key career pathways (community/hospital pharmacy and pharmaceutical industry), the thematic analysis yielded results similar to the TOMA analysis. A key concept scheme is described in Figure 5.

Corresponding with the theme of community pharmacy described in part 1 of the research, nearly half of the respondents displayed concerns over the changes in community pharmacy. A third of the student participants displayed both positive and

\section{KEY CAREER PATHWAYS IN PHARMACY}

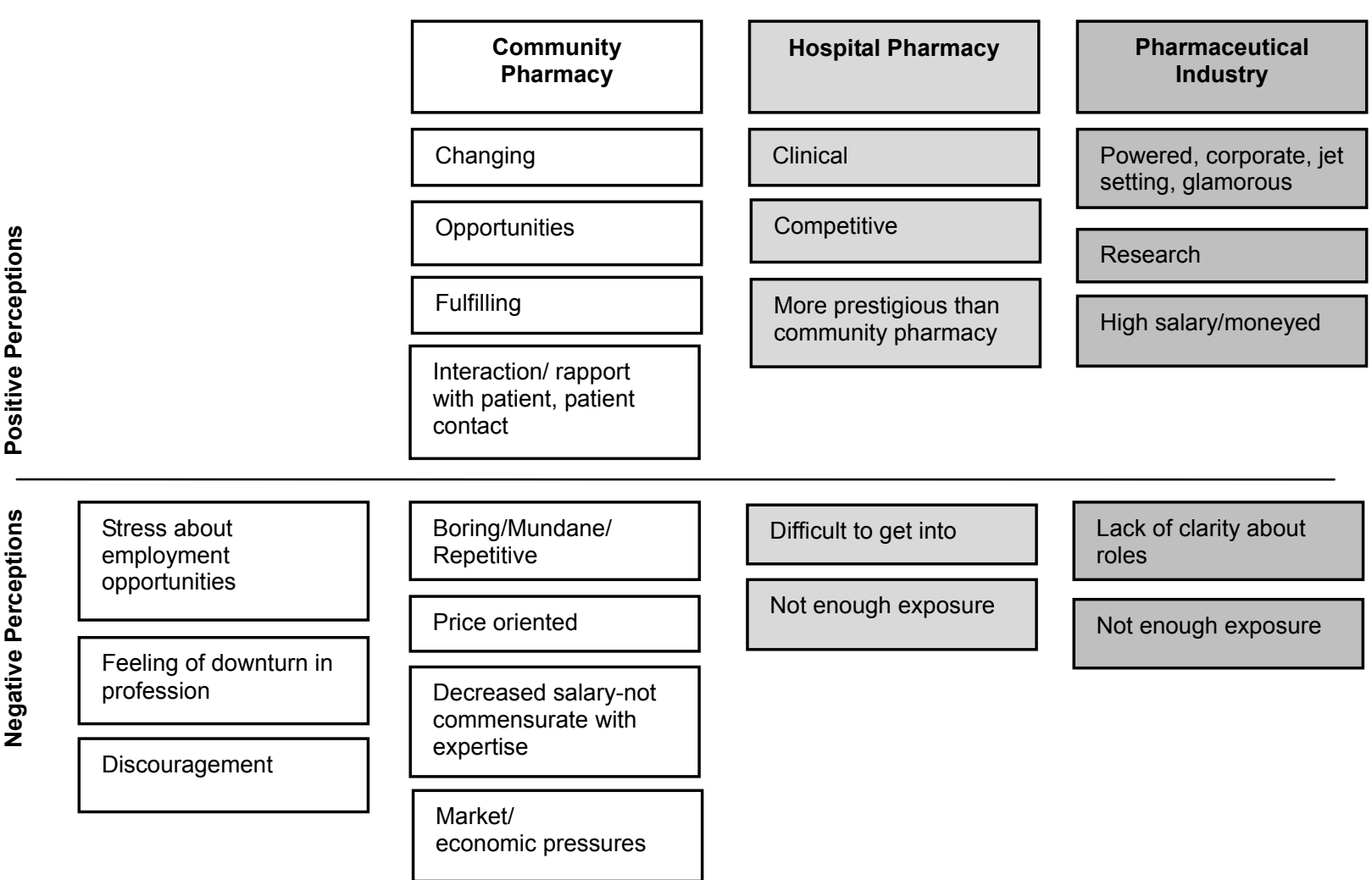

Figure 5. Concept map of students' positive and negative perception of community, hospital and industry pharmacy. 
negative perception and another third displayed positive perception of community pharmacy including patient care. Contrasting with community pharmacy, more than half of the participants had positive perceptions of hospital pharmacy relating to the nature of the work such as greater use of clinical knowledge and being part of the health care team. Overall, the pharmaceutical industry was perceived as a competitive field to enter with focus on business administration, commercial and research aspect of industry. The majority of participants perceived industry as offering career opportunities with high financial reward. A majority of students had little or no exposure to industry. Quotes exemplifying the key themes for each of the 3 career paths are appended (Online Appendix 1).

4.2 Perception of the pharmacy profession and general feedback

Out of 238 survey respondents, more than a quarter of the students expressed their thoughts of pharmacy in section 5 of the survey. Students indicated the need for more placements such as hospital or industry and many asked for career support and comments included:

An issue of concern is students' negative perception of the profession with more than a third of students expressing concern over job opportunities, decreasing wage, limited career paths, increasing number of pharmacy schools and limited reward for the amount of work involved as a pharmacist.

\section{DISCUSSION}

This research explored the career perspectives of current Australian final year pharmacy students about to embark on a professional life. The study examined the key socio-ecological factors that shape career development, such as the personal socio-demographic influences, reasons that had motivated students to choose pharmacy as career option and satisfaction with this choice they had undertaken throughout the degree. This is the first study exploring a wide range of career perspectives such as career intention, satisfaction with decision pharmacy as a under/post graduate leading to health professional registeration and views about joining differing pathways in the future final year Australian Pharmacy students. A mixed method approach was used to enrich the data obtained with both a cross-sectional survey of final year pharmacy students and a qualitative interview method being employed. Key results indicated that socioecological frameworks are a useful starting point in understanding the dynamic process that shapes career perceptions. Ethnicity and family history of pharmacy/health professional life, and a "true" interest in pharmacy predict satisfaction with the overall career choice. The qualitative results indicated that recent changes within the profession in Australia have affected students' perceptions about their career choice. The results have immediate relevance to the pharmacy professions' leadership and teaching institutions in Australia, and indeed, globally, as they suggest that a major turnaround in entry criteria, teaching, course experiences and general media messages must occur if young entrants are to be encouraged to stay in, develop careers and lead pharmacy to new horizons as a profession.

\section{Intrinsic and Extrinsic factors affecting choice of pharmacy as a tertiary course/future profession}

Our hypothesis for the study; specifically that individual factors affect choice of pharmacy as a course appeared to be correct. Linking back to the socio-ecological framework, the 'personal context' in career development was important, i.e. . motivators for choosing pharmacy as a tertiary course to study at University. The results suggest that it is usually a combination as opposed to single reasons which influence the choice to study pharmacy. The research revealed students' that intrinsic interest in health and medicine was the most important reason to study pharmacy followed by extrinsic factor such as status of profession and job prospect. The finding aligns with previous studies in the United States, United Kingdom, Australia, New Zealand, Malaysia and South Africa which found a combination of intrinsic factors (related to the individual) such as altruistic intention, desire to study scientific subjects and extrinsic factors (factors beyond the individual control) such as work environment and, career opportunities to be the most highly ranked factors for choosing pharmacy. ${ }^{15-29}$ While students chose pharmacy also due to the nature of the work such as patient contact, it is not surprising that pragmatic factors such as job prospect and high income expectation are also important factors for studying pharmacy. This may be explained by the global financial crisis in 2008 where current final year students' decision of career during a time of financial instability may be based on job stability, prospect and income.

\section{Satisfaction with the pharmacy course}

Next, the framework describes processes that shape career development. A majority of students were 'somewhat' satisfied with their decision to study pharmacy and the research found a higher proportion of students were 'not at all' satisfied compared to those who are 'extremely' satisfied. Interestingly, the study found that dissatisfaction with career decision was prevalent amongst students who chose pharmacy due to pragmatic reasons such as high income, or those who sought alternative career pathways such as health policy or medicine/dentistry. Previous research has highlighted that those who undertake pharmacy study not as a final career destination and have alternate degrees such as medicine in mind, are less satisfied with their career choice and thus continue to plan exit avenues into other careers. ${ }^{20,34}$ Further research is required to test the likelihood of these students staying in pharmacy for a better understanding of workforce retention. Overall, pharmacy students' dissatisfaction may ensue as a direct consequence of professional vibes; dissatisfaction with the profession's future has indeed led to workforce attrition among Australian pharmacists in recent times. ${ }^{35}$ Higher satisfaction trends were noticeable in students who had another 
tertiary degree or reported themselves to be of a White/Caucasian ethnic background. The former phenomenon is logical as those who chose to study pharmacy after a previous course of study have a strong motivation towards a career in pharmacy. Possibly the later observation may be explained by culture differences and past experience which suggests that White/Caucasian students are more likely to be familiar with pharmacy, have a higher understanding of the degree and awareness of a career in pharmacy. ${ }^{16}$ As hypothesised, good placement experiences seemed to associate with satisfaction in this study. This too has been demonstrated in the past and can also be explained as a positive process that shapes career development based on the Bronfenbrenner framework. $^{34,36,37}$

\section{Perception about future career pathways - opportunity for supporting students}

The perceptions towards various career pathways were expected. The real or perceived oversupply of employable pharmacists and negativity in the press about community pharmacy career prospects are reflected in students' perceptions. This has implications for education and professional pharmacy bodies in Australia to engage students in practice changes and together, to shape and lead a brighter future for the pharmacy profession. Students appear to express an interest in career paths such as hospital pharmacy and pharmaceutical industry, but it was also clear that students did not have much exposure to different types of placements. This is an opportunity for educators to design curricula to broaden students' skills and knowledge beyond the traditional pathway mostly aligned towards community pharmacy. Students also feel unsupported in terms of making career related decisions. This highlights the need for early career awareness, exposure to practice, advice and support prior to and throughout the degree to help better decision making to improve satisfaction with career choice. ${ }^{37-39}$ It would appear that designing a comprehensive career support mechanism across the degree may be useful. Research to evaluate student perceptions at different points in their course and the effect of career choice and development interventions would be a useful exercise. Recently similar research has been undertaken with Australian Nursing students, and has proven to be useful in elucidating insight into factors that shape nursing students' career related decisions. ${ }^{30}$

\section{Future research directions}

Further research could also focus on intern and early career pharmacists' perceptions to ascertain the influence of actual practice rather than perceptions portrayed by media reports.

Finally, it is interesting to note that discrepancy between students' expectation of the profession and brief experiences of actual practice are prompting students to consider alternative career pathways including dentistry or medicine. In addition, previous report suggests the lack of career progression is also a possible reason for pharmacists leaving the profession. ${ }^{13,14}$ Indeed, students' intention to practice pharmacy can be influenced by exposure to real practice throughout the professional degree as well as external influence such as job prospects and profession's image.

There are several limitations in this study. The cross sectional study was conducted at one point in time hence causal relationships cannot be established and future changes in the pharmacy market may influence students' satisfaction and perception. Also, the sample frame of final year students came from 3 universities in Australia and has limited generalizability across Australia and around the globe. The Masters level student sample was too small to draw any useful comparisons between the under/post graduate professional entry courses. Finally, it was hard to determine the absolute factors which impact on students' level of satisfaction and perception due to personal bias and experience across a four year degree.

\section{CONCLUSIONS}

Put together, the findings of this research suggest that pharmacy students' experience in education, employment and placement has influenced the way students perceive the traditional career pathways such as the community and hospital sectors. Changes in the profession appear to be prompting students to look beyond the traditional career path and prompting students to reflect on the reasons why they chose to study pharmacy and their satisfaction of this decision. Current circumstances suggest that pharmacists can no longer expect to be hired immediately for the job they seek. As such, early career advice and strategically positioned placement experience is essential for students to broaden their career perspectives beyond the traditional career pathways, to develop further skills and adapt to different roles. Educators and professional bodies have a critical role in shaping pharmacy curricula and establishing new roles for pharmacists to achieve meaningful career pathways in the changing environment.

\section{ACKNOWLEDGEMENTS}

The Faculty of Pharmacy, University of Sydney is acknowledged for providing infrastructure support for the research.

All participants from the 3 Universities are thanked for their participation in research.

Dr Libby Hotham from the University of South Australia is particularly acknowledged for her support in facilitating student recruitment.

\section{CONFLICT OF INTEREST}

None declared.

Funding: The project had no financial support other than institutional infrastructure support. 


\section{EXPERIENCIAS DEL CURSO, SATISFACCIÓN E INTENCIONES DE CARRERA DE LOS ESTUDIANTES DEL ULTIMO AÑO PRE- REGISTRO DE FARMACIA}

\section{RESUMEN}

Antecedentes: En Australia, la profesión de farmacia ha sufrido muchos cambios para adaptarse a las necesidades de la comunidad. En los últimos años han aparecido preocupaciones sobre la evidencia que se va produciendo de la saturación de mano de obra en los sectores tradicionales del ejercicio de la farmacia. No se sabe cómo perciben los actuales estudiantes del último año de farmacia las diferentes salidas profesionales en este entorno cambiante. Por ello, sería importante investigar las experiencias de los estudiantes con su curso, la interacción con la profesión y sería un paso importante evolucionar en la comprensión de sus intenciones de carrera, ya que estos estudiantes constituyen una gran proporción de la futura fuerza laboral de farmacia.

Objetivo: El objetivo de este estudio fue, por tanto, investigar en los estudiantes del último año, las perspectivas de carrera y las razones para la selección de farmacia, la satisfacción con su selección de farmacia como un curso terciario y la posible futura carrera profesional, los factores que afectan a la satisfacción y la intención de futuras salidas profesionales.

Métodos: Encuesta transversal cuantitativa a los estudiantes del último año de 3 Universidades australianas, seguida de entrevistas cualitativas semiestructuradas a una muestra de conveniencia a estudiantes del último año de la Universidad de Sydney. Resultados: El 'interés en la salud y la medicina' fue la razón más importante para elegir farmacia $(n=238)$. La mayoría de los estudiantes estaban 'algo satisfechos' con la elección de farmacia $(35,7 \%)$ como curso y posible ejercicio profesional. Se encontraron asociaciones positivas entre la satisfacción y razones para inscribirse en farmacia, tales como 'sentir que farmacia es una buena profesión’ ( $\mathrm{p}=0,003)$, mientras que las asociaciones negativas incluían 'inscribirse en farmacia como paso para medicina u odontología' $(p=0,001)$. Los resultados cualitativos y cuantitativos mostraron que las percepciones más frecuentes sobre los farmacéuticos comunitarios era 'cambiante', mientras que los farmacéuticos hospitalarios y la industria eran descritos como 'competitivos' e 'investigación', respectivamente. La intención de salida profesional más frecuente era la farmacia comunitaria, seguida de la hospitalaria. Conclusión: Factores complejos, que incluyen las experiencias universitarias, están involucrados en la conformación de la satisfacción y percepción de las salidas en los estudiantes. Estos pueden estar relacionados con retos en el sector de farmacia comunitaria, oportunidades de trabajo en hospital y entendimiento limitado de la industria farmacéutica. Los resultados ofrecen una aproximación para la profesión en términos de aparición de los varios papeles y también a los educadores por su papel en la conformación de currículos y selección de lugares de prácticas que atraigan a los futuros graduados a definir su carrera profesional en farmacia.

Palabras clave: Estudiantes de Farmacia; Selección de Profesión; Satisfacción Personal; Farmacéuticos; Servicios Farmacéuticos; Australia

\section{References}

1. Health Workforce 2025 - Doctors, Nurses and Midwives - Volume 1. Health Workforce Australia , Council of Australian Governments. Available at: http://www.hwa.gov.au/sites/uploads/FinalReport_Volume1_FINAL-20120424.pdf (Accessed October 24, 2012)

2. Community Pharmacy Agreement. The Pharmacy Guild of Australia. Available at: http://www.guild.org.au/The_Guild/tabTheGuild/Community_Pharmacy_Agreements/Community+Pharmacy+Agreement.page (Accessed June 7, 2012).

3. Benrimoj SI, Frommer MS. Community pharmacy in Australia. Aust Health Rev. 2004;28(2):238-246.

4. O'Donoghue N. Supermarkets to sell ibuprofen and phenylephrine combos, Pharmacy News. 6 September, 2012.

5. O'Donoghue N. Pharmacy turnover in decline: ABS. Pharmacy News. 4 September 2012.

6. O'Donoghue N. Bankruptcy rates soar. Pharmacy News. 19 August, 2013.

7. O'Donoghue N. Guild predicts large increase in graduate numbers. Pharmacy News. 20 June, 2012.

8. Sclavos K. Pharmacist employment market. Aust J Pharm. 2011;92(1098):Article 18.

9. O'Donoghue N. Guild backs call for moratorium on pharmacy schools. Pharmacy News. 20 July, 2011.

10. O'Donoghue N. Jobs plentiful, but pay low, for pharmacy graduates. Pharmacy News. 14 December, 2011.

11. O'Donoghue N. Walk into a job with a pharmacy degree: report. Pharmacy News. 29 August, 2012.

12. Cowling K. Pharmacists deserve higher pay rates. Pharmacy News. 13 August, 2012.

13. Lee J, Mak V. Early career pharmacists working group (ECPWG) response to PSA issues paper on the future of pharmacy: Pharmaceutical Society of Australia. 2010. Available at: http://www.psa.org.au/download/early-careerpharmacists/ECPWG-response-to-future-of-pharmacy-review.pdf (Accessed May 1, 2012).

14. O'Reilly C. PSA Early career pharmacists survey report 2010. Pharmaceutical Society of Australia. 2010. Available at: http://www.psa.org.au/download/early-career-pharmacists/ecp-survey-report.pdf (Accessed May 1, 2012).

15. Anderson DC, Sheffield MC, Hill AM, Cobb HH. Influences on pharmacy students' decision to pursue a doctor of pharmacy degree. Am J Pharm Educ. 2008;72(2):22.

16. Keshishian F. Factors influencing pharmacy students' choice of major and its relationship to anticipatory socialization. Am J Pharm Educ. 2010;74(4):75

17. Savage LM, Beall JW, Woolley TW. Factors that influence the career goals of pharmacy students. Am J Pharm Educ. 2009;73(2):28

18. Siracuse MV, Schondelmeyer SW, Hadsall RS, Schommer JC. Third-year pharmacy students' work experience and attitudes and perceptions of the pharmacy profession. Am J Pharm Educ. 2008;72(3):50.

19. Willis SC, Hassell K, Noyce P. Career intentions of pharmacy students. J Health Serv Res Policy. 2008;13(Suppl 2):4551. doi: $10.1258 /$ jhsrp. 2007.007112 
20. Willis SC, Shann P, Hassell K. Pharmacy career deciding: making choice a "good fit". J Health Organ Manag. 2009;23(1):85-102.

21. Davey A, Evans AM, Stupans I. Pharmacy: Factors that influence the choice of career and study options. Pharm Educ. 2006;6(1):21-26.

22. Simpson MD, Wilkinson JM. The first graduate cohort at Charles Sturt University: What impact on the rural pharmacist shortage? J Pharm Pract and Res. 2002;32(1):69-71.

23. Taylor SJ, Maharaj P, Williams K, Sheldrake C. Pharmacy students' intention to practise in a rural setting: measuring the impact of a rural curriculum, rural campus and rural placement on a predominantly metropolitan student cohort. Aust J Rural Health. 2009;17(6):305-309. doi: 10.1111/j.1440-1584.2009.01102.x

24. Capstick S, Beresford R. A comparison of student attitudes and intentions at the start and end of their BPharm degree programme. Pharm Educ. 2007;7(3):267-277.

25. Capstick S, Green J, Beresford R. Choosing a course of study and career in pharmacy - student attitudes and intentions across three years at a New Zealand School of Pharmacy. Pharm Educ. 2007;7(4):359-373.

26. Modipa SI, Dambisya YM. Profile and career preferences of pharmacy students at the University of Limpopo, Turfloop campus, South Africa. Educ Health (Abingdon). 2008;21(3):164.

27. Hasan SS, Kwai Chong DW, Ahmadi K, Se WP, Hassali MA, Hata EM, Hadi MA, Sridhar SB, Ahmed SI, Yean LB, Efendie B. Influences on Malaysian pharmacy students' career preferences. Am J Pharm Educ. 2010;74(9):166.

28. Kirby-Smith J, Portlock J, Brown D. Investigation of student views on industrial pharmacy. Pharm Educ. 2008;8(1):7-11.

29. Marrone CM, Ruble GC. Change in student perception after a pharmaceutical industry advanced pharmacy practice experience. Drug Inf J. 2010;44(2):131-136.

30. Price S. Future directions for career choice research in nursing: a discussion paper. Int J Nurs Stud. 2009 Feb;46(2):268-276. doi: 10.1016/j.ijnurstu.2008.07.011

31. Hickey N, Harrison L, Sumsion J. Using a socioecological framework to understand the career choices of single- and double-degree nursing students and double-degree graduates. ISRN Nurs. 2012;2012:748238. doi: $10.5402 / 2012 / 748238$

32. Lerner R. Making human beings human: bioecological perspectives on human development. California: Sage Publications; 2005.

33. Bronfenbrenner U. Interacting systems in human development. Research paradigms: present and future. In: Bolger $\mathrm{N}$, Caspi A, Downey G, Moorehouse M, eds. Persons in Context: Developmental Processes. New York, NY: Cambridge University Press; 1988.

34. Wilson K, Jesson J, Langley C, Hatfield K, Clarke L. Pharmacy undergraduate students: Career choices \& expectations across a four-year degree programme. London: Royal Pharmaceutical Society of Great Britain. 2006:99. Available at: http://www.pprt.org.uk/documents/publications/pharmacy_undergraduate_students_career_choices_and_expectations.p df (Accessed October 25, 2012).

35. Mak VS, March GJ, Clark A, Gilbert AL. Why do Australian registered pharmacists leave the profession? a qualitative study. Int J Clin Pharm. 2013 Feb;35(1):129-137 doi: 10.1007/s11096-012-9720-5

36. Kiersma ME, Plake KS, Newton GD, Mason HL. Factors affecting prepharmacy students' perceptions of the professional role of pharmacists. Am J Pharm Educ. 2010;74(9):161.

37. Mak VS, March GJ, Clark A, Gilbert AL. Australian intern pharmacists' perceived preparedness for practice, and their expectations and experiences of the internship year and future career intentions. Integ Pharm Res Prac.2013 2:25-34. doi: 10.2147/IPRP.S50387

38. Mahoney R, Katona C, Mcparland M, Noble L, Livingston G. Shortage specialties: changes in career intentions from medical student to newly qualified doctor. Med Teach. 2004;26(7):650-654.

39. Larsen PD, McGill JS, Palmer SJ. Factors influencing career decisions: Perspectives of nursing students in three types of programs. J Nurs Educ. 2003;42(4):168-173. 